\title{
Cost Returns and Input use Pattern for French Bean Cultivation in Mysore District of Karnataka, India
}

\author{
R. Raghupathi ${ }^{1 *}$, G. S. Mahadevaiah ${ }^{2}$, G. M. Gaddi ${ }^{3}$ and M. J. Anjan Kumar ${ }^{4}$ \\ Department of Agricultural Economics, College of UAS, GKVK Bengaluru-560065, India \\ *Corresponding author
}

\begin{abstract}
A B S T R A C T
The present study is an attempt to estimate the economics and input use pattern of French bean (Phaseolus vulgaris L.)Producing farms in Mysore district of Karnataka, where French bean is cultivated extensively. Descriptive statistics were used for estimating the input use pattern of cultivation of Arka Sharath and Ashoka variety of French bean farmers. The study is based on the primary data collected from 70 randomly chosen French bean cultivators comprising of 35 sample farmers each growing Arka Sharath and check varieties (Ashok) of French beans. The results revealed that farmers realized 30 per cent higher gross returns (Rs. 2,62,500acre ${ }^{-1}$ ) from cultivation of Arka Sharath as pure crop compared the cultivating check variety (Rs. 1,84,990 acre ${ }^{-1}$ )which indicated cultivation of Arka Sharath was more efficient compared to check variety. The results of the descriptive statistics analysis revealed that the human labor, machine labor, seedlings, chemical fertilizers and plant protection chemicals of Arka Sharath variety was Rs. $21,620,2,585,5,480,2,598$ and 4,271 per acre respectively while in case of check variety was Rs. 13,462, 632, 4,260, 2,350, and 7,042 per acre respectively.
\end{abstract} Keywords

Descriptive statistics analysis cost and returns

Article Info

Accepted:

12 February 2020 Available Online: 10 March 2020

\section{Introduction}

Beans are a large group of leguminous vegetables that serve as the main source of proteins in the vegetarian human diet. French bean is also known as 'meat of the poor'1, 'grain of hope'2 and 'Superfood'3. It is one of the highly relished pulses because of its rich nutritional composition. Majority of the population in India being vegetarian, increased consumption of French bean will supplement their nutritional requirement. In southern Karnataka, French bean is extensively grown as a vegetable for fresh pods.

The productivity of French bean is lower cultivate of traditional varieties which are low yielding and the prone to attack of pest and diseases realized in low yield and income to the farmers. French bean (Phaseolus vulgaris L.) is one of the most important leguminous 
vegetable crops in India. It is known by many names such as a bush bean, common bean, dry bean, dwarf bean, green bean, haricot bean, kidney bean, navy bean, pole bean, rajma, snap bean, string bean, tepary bean or wax bean.

It is extensively grown as an intercrop rather than as sole crop. The main constraint expressed by farmers when grown as an intercrop of French bean is low productivity. The main reasons for its extensive cultivation include its short duration, high nutritive values, soil fertility enhancing capacity and wider adoptability.

\section{Technology profile}

Arka Sharath is the high yielding variety. This variety was developed and identified for paste under the leadership of $\mathrm{Dr}$ T. S Agora, Principal Scientist, and Division of Vegetables. The protocols for the paste were developed by Dr Doreyappa Gowda and his team of Division of Post-harvest Technology and Agricultural Engg.

The field and paste quality evaluation of these varieties was carried out at the Institute by Variety and technology evaluation committee (VTIC). Arka sharath was found superior for desirable parameterslike round, string less, smooth pods suitable for steamed beans. Pods are crisp, fleshy with no parchment and perfectly round on cross section.

Plants are bushy and photo insensitive and it is suitable for both kharif and rabiseasons.It gives maximum number of pods per plant (44.5) compared to checks. It has high pod yield potential of $18.5 \mathrm{t} / \mathrm{ha}$ in 70 days. The special characteristics of Arka Sharath include high yielding, short duration, yellow mosaic virus (YMV) disease tolerant, plants are bushy and photo insensitive, good quality pods with good keeping quality.
Parameters to be measured in relation to the technology

\author{
Pod diameter \\ Pod color \\ Pod weight \\ Pod yield
}

Market Rate.

In the present study has attempted to analyse the input use pattern, estimate the economics and constraints involved in cultivation of French bean. Findings of the study would help the followed by farmers, policy maker's researcher and to take appropriate decisions for enhancing productivity and production.

\section{Materials and Methods}

To assess the economics and input use pattern of French bean cultivation, the required primary data were collected from 70 farmers in Mysore districts of Karnataka, comprising of 35 farmers cultivating Arka Sharath and 35 farmers growing local varieties (Ashok) of French bean under irrigated condition the data were collected through personnel interviews with the help of pretested schedule designed for the study.

Data were analysed using the descriptive statistics technique. Arka sharath variety of French bean released from Indian Institute of Horticultural Research (IIHR), Bangalore is selected for the study.

\section{Descriptive statistics}

Descriptive statistics provide simple summaries about the sample and about the observations that have been made. It deals with the presentation of numerical facts, or 
data, in either tables or graph form, and with the methodology of analyzing the data.

\section{Input and cost concepts}

The total costs were divided into two broad categories:

\section{a. Variable Costs \\ b. Fixed Costs \\ Variable costs}

The variable costs include cost of seeds, manure, fertilizers, wages of human and bullock labour, machine labour, plant protection chemicals, miscellaneous charges interest on working capital and repair and maintenance charges.

\section{Seeds}

The cost of purchased seeds was based on the actual amount paid by the respondents.

\section{Farm yard manure}

The quantity of FYM used in the cultivation of paddy was measured in terms of. The cost was imputed at the market price in the village including cost of transportation and other incidental charges if any.

\section{Fertilizers and plant protection chemicals}

The cost of fertilizers and plant protection chemicals was based on the actual prices paid by the farmers including the cost of transportation and other incidental charges, if any.

\section{Labour}

The cost of hired labour was calculated at the prevailing wage rates paid per day ( 8 hours) in the study area for Men, Women and
Bullock labours and Machine labour during the study period.

The cost of family labour human, animal and machinery) was calculated considering the prevailing market rate in this region through imputation.

\section{Miscellaneous charges}

This includes the expenses incurred by sample farmers for procuring input materials and marketing of produce in the market and other expenses.

\section{Interest on working capital}

The working capital consists of the expenditure on seeds, labour, farm yard manure, chemical fertilizers and plant protection chemicals, Interest on operational capital was calculated at the rate of 7 per cent per annum (the rate at which commercial banks advance short term loans).

\section{Fixed costs}

These include depreciation on farm implements and machinery, interest on fixed capital, land revenue.

The measurement and definitions of fixed cost components are as follows.

\section{Depreciation charges}

Depreciation on each capital equipment and machinery owned by the farmers and used for land cultivation was calculated for individual farmer based on the purchase value using the straight line method. Thus the

Annual depreciation $=$ Purchase value - Junk value 


\section{Useful life of the asset}

The average life of the asset as indicated by the experts (Agril. Engineers) was used in the computation of the depreciation. The depreciation costs of each equipment were apportioned to the crop based on its percentage use.

\section{Interest on fixed capital}

Interest charges on fixed capital were calculated at the rate of 9 per cent, as the fixed deposits in commercial banks would fetch this rate of interest. The items considered under fixed capital are implements and machinery. Interest was considered on the value of these assets after deducting the depreciation for the year.

\section{Land revenue}

Actual land revenue paid by the farmers was considered.

\section{Rental value of land}

It was imputed by taking the prevailing rents in the study area per acre per annum.

\section{Cost of cultivation}

It is the sum of variable costs and fixed costs and expressed on per acre basis.

\section{Gross return}

The gross returns were computed by multiplying the quantity of main product and by-product obtained with respective prices received.

\section{Results and Discussion}

It could be observed from the Table 4.1 that total variable, fixed costs and total cost of cultivation of Arka Sharath and Ashoka varieties and the per cent change in these costs of Arka Sharath over the check variety.

There was not much difference in case of fixed costs. But, there was 20 per cent difference in case of variable costs between the two varieties i.e., Arka Sharath had 20 per cent higher variable cost compared to the check variety. Overall, Arka Sharath had higher cost of cultivation i.e.17 per cent higher cost of cultivation compared to the check variety.

In case of variable costs, Arka Sharath had higher costs with respect to Human labour, machine labour, FYM and irrigation. While, Check variety had higher variable costs in case of bullock labour, PPC and transportation costs. The increase in human labour use in Arka Sharath is, because it demands more pickings compared to check variety and lesser use of PPC is, because it is more resistant to pests and diseases compared to the check variety.

The above Table 4.2 depicts that the difference in yield, price per tonne and returns from Arka Sharath and Ashoka. Arka Sharath has higher yield, higher price per tonne, higher returns compared to the check variety. Arka Sharath has 19 per cent higher yield, 30 per cent higher gross returns, 37.3 per cent higher net returns and 13 per cent higher price per tonne compared to the check variety.

The high yield is due to the increased number of pickings compared to the check variety and higher price per tone is because it has longer shelf life, increased nutritional value and its suitability for export. The input use pattern of Arka Sharath and Ashoka variety was depicted in the Table 4.3. The average input i.e., human labour (Rs. 21,620) was highest input use in both varieties and it was higher in Arka Sharath variety compared to Ashoka variety 
Table.1 Comparative Economics of Arka Sharath Variety and Check Variety of French bean cultivation (Rs. / acre)

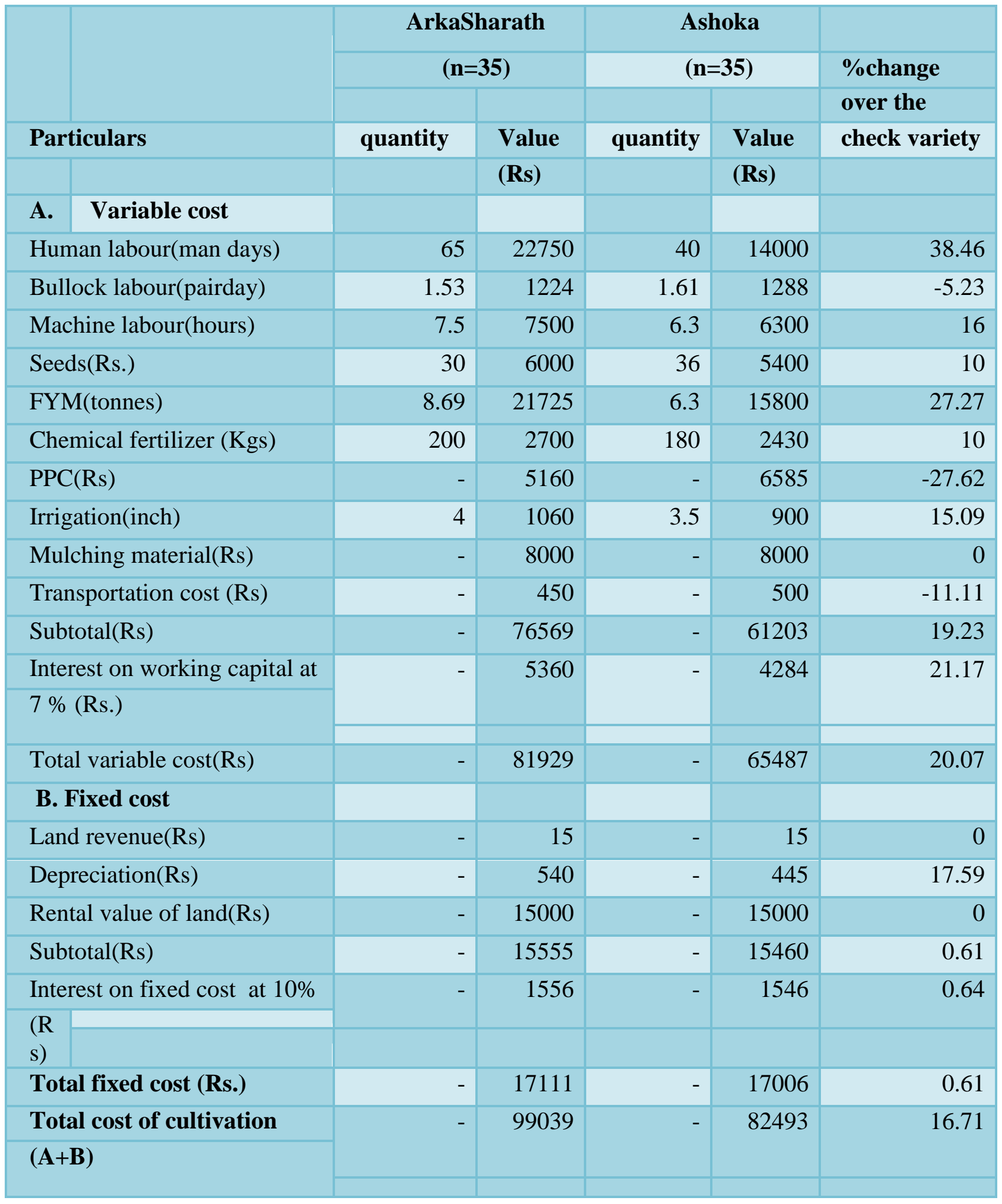


Table.2 Yield and returns from French bean cultivation (Per acre)

\begin{tabular}{|l|r|r|r|}
\hline \multicolumn{1}{|c|}{ Yield and Returns } & Arka Sharath (n=35) & Ashoka (n=35) & $\begin{array}{c}\text { \%change over } \\
\text { the check } \\
\text { variety }\end{array}$ \\
\hline Yield (tonns/acre) & 17.50 & 14.23 & 18.69 \\
\hline Gross Returns(Rs) & $2,62,500$ & $1,84,990$ & 29.53 \\
\hline Net returns(Rs) & $1,63,461$ & $1,02,497$ & 37.30 \\
\hline Price received (Rs/tonn) & 15,000 & 13,000 & 13.33 \\
\hline $\begin{array}{l}\text { Returns per rupee of } \\
\text { investment }\end{array}$ & 2.65 & 2.24 & - \\
\hline
\end{tabular}

Table.3 Input use pattern for Arka Sharath and Ashoka variety

\begin{tabular}{|c|c|c|c|c|c|c|c|c|}
\hline \multirow[t]{2}{*}{ Variables } & \multicolumn{3}{|c|}{$\begin{array}{l}\text { Arka Sharath } \\
\text { variety }(n=35)\end{array}$} & & & \multicolumn{2}{|c|}{ Ashoka variety $(\mathrm{n}=\mathbf{3 5})$} & \multirow[b]{2}{*}{$\max$} \\
\hline & Mean & S.D & Min & $\max$ & Mean & S.D & $\min$ & \\
\hline Area under & & & & & & & & \\
\hline French bean & 1.1 & 0.48 & 0.5 & 2 & 1.01 & 0.53 & 0.5 & 2 \\
\hline (acre) & & & & & & & & \\
\hline Human & 21,620 & 4,706 & 15,000 & 31,100 & 13,462 & 4,553 & 6,800 & 27,000 \\
\hline $\begin{array}{l}\text { Machine } \\
\text { labour }\end{array}$ & 2,585 & 1,758 & 750 & 6,220 & 632 & 275 & 300 & 1,300 \\
\hline (hrs) & & & & & & & & \\
\hline Seedlings (No) & 5,480 & 1,832 & 2,800 & 9,000 & 4,260 & 1,719 & 2,100 & 7,500 \\
\hline $\begin{array}{l}\text { Chemical } \\
\text { fertilizers (Rs) }\end{array}$ & 2,598 & 1,066 & 1,350 & 5,050 & 2,350 & 1,211 & 1,350 & 5,050 \\
\hline PPC(Rs) & 4,271 & 1,521 & 1,500 & 8,000 & 7,042 & 2,170 & 3,000 & 12,000 \\
\hline $\begin{array}{l}\text { Gross return } \\
\text { (Rs) }\end{array}$ & $2,41,485$ & $1,02,372$ & $2,25,000$ & $6,25,000$ & $1,14,681$ & $1,66,002$ & 50,000 & $3,12,500$ \\
\hline
\end{tabular}

The average input use of Arka Sharath was more in machine labour (Rs. 2,585), seeds (Rs. 5,480), chemical fertilizers (Rs. 2,598) compared to Ashoka variety. The average input use of Ashoka variety was more in plant protection chemicals (Rs. 7,042) compared to Arka Kamini variety.

The gross returns realized by the Arka Sharth farmers growing as pure crop was Rs. 2,62,500,per acre whereas it was Rs. $1,84,990$ by check variety (local variety of French bean) farmers with a difference of Rs. 77,510 per acre, higher than check variety of Farms. The net return of Arka sharath was the higher (Rs. 1,63,461per acre) Arka Sharath of French bean farms than (Rs. 1,02,497per acre) for check variety farms, with a difference of Rs. 60,964 higher than the local variety of French bean. The results of the descriptive statistics 
analysis shows that the human labor, machine labor, seedlings, chemical fertilizers and plant protection chemicals of Arka Sharath variety was Rs. 21,620, 2,585, 5,480, 2,598 and 4,271 per acre respectively while in case of check variety was Rs. 13,462, 632, 4,260, 2,350, and 7,042 per acre respectively.

Input use pattern have been estimated for one of the important vegetables, viz. French bean using descriptive statistics analysis. The variables influencing Input use pattern the of French bean production have been analysed determined using the descriptive statistics. The input use pattern in French bean production among different categories of farmers highlighted that most of the applied inputs were found to be in lower than the recommended acreage. This suggests that there is potential to increase the overall production, by in French bean cultivation.

The Arka Sharath variety of French bean performing well in field conditions and offering higher returns to the farmers in comparison with check varieties. The main emphasis of this study is on increasing the production, income and employment opportunity at farmer's level. In this context, the study will be of great importance to recognize whether the improved IIHR (Indian Institute of Horticultural Research) technology verities is profitable and whether it has provided additional production opportunities to the technology adopters.

\section{References}

Bahirat, J.B. and Jadhav, H.G., 2011, Cost returns and profitability of rose production in Satara District, Maharashtra. The Asian J. Hortic., 6 (2): 313-315.

Jethendra, B. K., 2007, Comparative study of Hi-Tech and field Rose cultivation around Bangalore City.M.Sc.Thesis (Unpub.). Mahatma Pule Krishi Vidyapeeth, Rahuri, Maharashtra.

Letaa, E., Kabungo, C., Katungi, E., Ojara, M. and Ndunguru, A., 2015.Farm level adoption and spatial diffusion of improved common Bean varieties in Southern Highlands of Tanzania.African Crop Science Journal, 23(3): 261- 277.

Prabhakara Rao, M., Shareef, S.M. and Raju, V.T., 1992, Costs and returns of jasmine cultivation in Guntur-district, Andhra Pradesh.South Indian. J. Hort., 40(2): 100-104.

Santhi, V.P., Raja, P., Anita, B. and Selvaraj, N., 2015, Evaluation of french beans (Phaseolus vulgaris L.) bush type at mid and higher elevations of Nilgiris. Asian Journal of Horticulture, 10(1): 100-104.

\section{How to cite this article:}

Raghupathi. R., G. S. Mahadevaiah, G. M. Gaddi and Anjan Kumar. M. J. 2020. Cost Returns and Input use Pattern for French Bean Cultivation in Mysore District of Karnataka, India. Int.J.Curr.Microbiol.App.Sci. 9(03): 1586-1592. doi: https://doi.org/10.20546/ijcmas.2020.903.186 